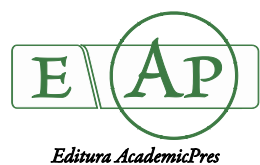

\title{
The Allelopathic Potential of Cirsium oleraceum (L.) Scop. into the Fodder Meadow Plants
}

\author{
Beata BARABASZ-KRASNY1 , Katarzyna MOŻDŻEŃ²*, \\ Anna SOETYS-LELEK ${ }^{3}$, Alina STACHURSKA-SWAKON' ${ }^{4}$ \\ ${ }^{1}$ Pedagogical University, Institute of Biology, Department of Botany, Podchorażych 2, 30-084 Kraków, Poland; bbk@up.krakow.pl \\ ${ }^{2}$ Pedagogical University, Institute of Biology, Department of Plant Physiology, Podchorązych 2, 30-084 Kraków, \\ Poland; kasiamozdzen@interia.pl ( ${ }^{*}$ corresponding author) \\ ${ }^{3}$ Ojców National Park, Ojców 9, 32-045 Sutoszowa, Poland; ana_soltys@wp.pl \\ ${ }_{4}^{4}$ Jagiellonian University, Institute of Botany, Kopernika 27, 31-501 Kraków, Poland; alina.stachurska-swakon@uj.edu.pl
}

\begin{abstract}
Due to easy vegetative and generative reproduction, the most part of the Cirsium species are considered as common weeds in different kinds of crops, on meadows and pastures. They owe their success in acquiring new area, both morphological and physiological characteristics, such as the production of allelopathic substances. An example the species within of the Cirsium genus, which may have the allelopathic properties, is cabbage thistle C. oleraceum (L.) Scop. It is a common meadow perennial plant, which in disturbed habitats quickly becomes expansive species, eliminating the other components of the flora. Such phenomenon is well-documented on the meadows of the Ojców National Park (Southern Poland). Therefore, it was investigated the effect of aqueous extracts of dried leaves $C$. oleraceum on seed germination, seedlings growth, the fresh and dry weight and the water content of the seedlings in three meadow species: Trifolium pratense L., Lolium multiflorum Lam. and Dactylis glomerata L. The results showed that C. oleraceum exhibits the allelopathic potential, which may have limited effect on the studied parameters of fodder species, but only when using high concentrations of extracts prepared from the leaves (15\% and 20\%). D. glomerata was the most sensitive on the C. oleraceum allelopathic substances.
\end{abstract}

Keywords: allelopathy, Dactylis glomerata, fresh and dry weight, Lolium multiflorum, morphology, seedlings, Trifolium pratense

\section{Introduction}

Allelopathic compounds are secreted by alive or dead organisms, during the decomposition of organic matter. The allelopathic substances secreted from the leaves or roots have inhibitory or stimulatory effect on the growth and development of other plants. They are produced by plants, not only in natural ecosystems, but also in semi-natural or anthropogenic ecosystems. They have influence on the composition of the plant communities, especially in the case of for mass distribution of species, which produces such compounds (Ahmed and Wardle, 1994, Wójcik-Wójtkowiak et al., 1998).

The cabbage thistle Cirsium oleraceum (L.) Scop. (Asteraceae family) is an example of a species that could potentially to have allelopathic properties. It is a common, grand and perennial plant growing in Asia and Europe (except the Mediterranean area). In Poland it grows on the whole area, especially in the lowlands and at lower altitudes, having the status of native species. Its erected, empty inside, stalk reaches a height of $0.5-1.5 \mathrm{~m}(1.8 \mathrm{~m})$. Leaves are through the entire length of the stalk, but the lower are ragged and significantly larger than the top. It prefers wet meadows habitats, tall herb communities, alluvia, the banks of ditches and water reservoirs, especially in fertile, moist and rich in calcium carbonate (Mowszowicz, 1986). In the classification of plant communities, this species is characteristic for the Calthion palustris R.Tx. 1936 em. Oberd. 1957 order and AngelicoCirsietum oleracei R.Tx. 1937 em. Oberd. 1967 association (Matuszkiewicz, 2006). It may en masse appear in the limestone meadows (Nawara, 2006), causing the gradual elimination of other floristic components. This kind of phenomenon was well documented on areas of valley meadows of the Ojców National Park (ONP) in Southern Poland (Kornaś and Dubiel, 1991). From the point of view of biodiversity conservation meadow ecosystems of the park, the 
256

species have caused significant changes in floristic composition. Therefore, in order to effectively protect semi-natural meadow communities it is important to get to know the allelopathic potential of $C$. oleraceum, compared to other common meadow plants.

The aim of the present study was to determine the effect of aqueous extracts of dry leaves $C$. oleraceum on the seeds germination (1), the growth (2), the fresh and dry weight (3) and the water content of the seedlings (4) of the three forage species: Trifolium pratense L. cv 'Dajana-C/1PL430/09/ 10060/Z47/A', Lolium multiflorum Lam. cv 'Mitos-C/1PL 430/09/10060/Z8/A' and Dactylis glomerata L. cv 'AthosC/1 DK-13NA0660'. These experiments were conducted to help answer the question: 'whether $C$. oleraceum has the ability to allelopathic influence on the species of sward'?

\section{Materials and Methods}

\section{Plantmaterial}

Specimens of Cirsium oleraceum (L.) Scop. were collected at the turn of June and July 2015 in one of the valley meadows, occurring in ONP - Fig. (1), (Southern Poland, N $19^{\circ} 4655,979^{\prime \prime} \mathrm{E} \quad 50^{\circ} 15^{\prime} 4,086^{\prime \prime N}$; E - 1951'11,998"E

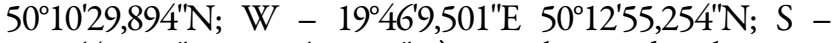
$\left.19^{\circ} 50^{\prime} 47,379^{\prime \prime} \mathrm{E} 50^{\circ} 10^{\prime} 13,017^{\prime \prime N}\right)$. In this study, the most commonly meadow plant species used as mixtures of component to sow meadows in order to regenerate them were selected. The seeds of Dactylis glomerata L. cv. 'Athos-C/1 DK-13NA0660', Lolium multiflorum Lam. cv. 'Mitos-C/1PL430/09/10060/Z8/ A' and Trifolium pratense L. cv. 'Dajana-C/1PL430/09/10060/ Z47/A', were bought in "KADO" Grass Warehouse s.c. A. Rydzewska, D. Rydzewski (Pszczyna, Poland).

\section{Preparation of extracts}

The aqueous extracts of $C$. oleraceum at concentrations of 1,5 , $10,15,20 \%$ from the leaves dried at room temperature and crushed in a mortar were prepared. Each of the extracts, depending on the concentration, were prepared in appropriate amounts of cold distilled water $(1 \%-99 \mathrm{ml}, 5 \%-95 \mathrm{ml}, 10 \%-90 \mathrm{ml}, 15 \%-$ $85 \mathrm{ml}, 20 \%-80 \mathrm{ml}$ ) and they were left for $24 \mathrm{~h}$ at a temperature of $25^{\circ} \mathrm{C}$ in order to extract allelopathic compounds. After 24 hours, the aqueous extracts were filtered and stored in the refrigerator no longer than a week.

\section{Germination of seeds}

Morphologically similar seeds of D. glomerata, L. multiflorum and $T$. pratense were washed with tap and distilled water. After then, on the Petri dishes, sterilised at $105^{\circ} \mathrm{C}$ and with filter paper, the 25 seeds of each plant were placed. Then seeds were watered the aqueous extracts of $C$. oleraceum dried leaves. The plant materials were placed in seed tray, at a temperature approx. $25^{\circ} \mathrm{C}$. At 24 hours for seven days it was checked number (percentage) of germinated seeds in order to determine their energy and power of seeds germination. As germinated seeds were considered those whose sprouts were longer than one half of the seed.

\section{Length of seedlings, fresh and dry weight and water content}

The allelopathic effect of aqueous extracts of the leaves of $C$. oleraceum on the growth of studied species seedlings (underground and aboveground organs) was measured after seven days from the start of the experiment. The fresh weight of seven day old seedlings was weighed (1600 C Medicat, Poland). To obtain a dry weight, the plant material was dried at $105^{\circ} \mathrm{C}$ in drier (Termaks 8430, Poland). The material was weighed and the dry weight and percentage of water content were determined.

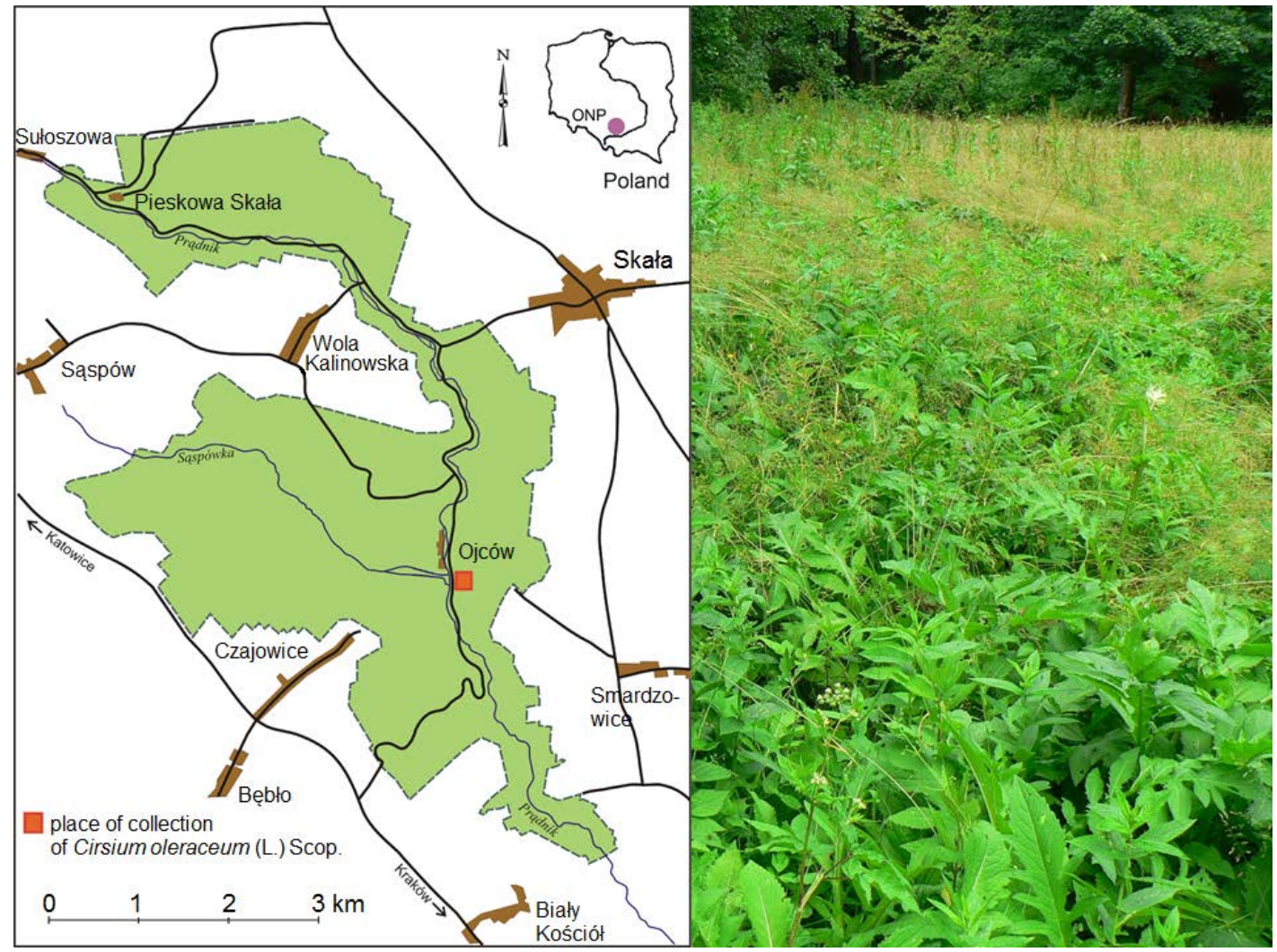

Fig. 1. Cirsium oleraceum on the meadow Ojców National Park from which the samples were taken 


\section{Statistical analysis}

The results are the arithmetic average of five independent replicates $(n=5)$ for each extract concentration and control group (distilled water). Besides average values, the standard deviations $( \pm S D)$ were also given. Statistical analysis was performed using non-parametric Kruskal-Wallis test after the Levene's test of variance homogeneity, wherein $\alpha=0.05$. The Statistica 10.0 software for Windows was applied to perform calculations.

\section{Results}

\section{Germination of seeds}

The aqueous extracts of the leaves Cirsium oleraceum (L.) Scop. demonstrated varying effects on seed germination of studied forage species (Fig. 2a-c). For example, on the 1\% extract concentration, the Trifolium pratense L. seeds germinated as the same as seeds watered distilled water (control). With the increase in the concentrations of the extracts, inhibition of germination was observed in each sample. In the $3^{\text {rd }}$ day, the energy of seed germination $T$. pratense was almost 60\%, Lolium multiflorum Lam. 23\%, and Dactylis glomerata L. 0\% (no germination). On the $15 \%$ and $20 \%$ extracts of $C$. oleraceum, the lowest number of germinated seeds was noticed - from 5 to $20 \%$ for $T$. pratense and $L$. multiflorum and $0 \%$ for $D$. glomerata. In following days, the number of germinated seeds studied species was changed only in minor degree, compared to seeds germinated in the first three days. Generally, on the extracts of $C$. oleraceum, the highest energy and power of seeds germination were observed for $T$.pratense, and the lowest for D. glomerata.

\section{Length of seedlings}

The length of the seedlings underground organs of $T$. pratense and $L$. multiflorum were not significantly different from control and 1\% leaves extract C. oleraceum (Fig. 3a-c). The D. glomerata seedlings in each of the concentrations used extracts showed significant inhibition of growth of underground organs as compared to control. In the case of $T$. pratense, significant inhibition the root growth on the $10 \%$, $15 \%$ and $20 \%$ extracts concentration was observed. While, the L. multiflorum was also sensitive to the extract with a $5 \%$ concentration. In the case of $20 \%$ extracts, complete inhibition of roots growth in all three species seedlings were observed. In addition, the $15 \%$ extract of $C$. oleraceum inhibited roots growth of $L$. multiflorum and the $10 \%$ extract also inhibited roots growth of $D$. glomerata.

In the case of aboveground organs, in almost all of the studied species a significant inhibition of seedlings growth were revealed. The absence of statistically significant differences between control and extract $1 \%$ were observed for $L$. multiflorum only (Fig. 3a-c). With increasing concentration of allelopathins, a decrease in growth of aboveground organs was observed, and even complete inhibition of growth on the $20 \%$ extracts for all studied seedlings. In addition to a growth of aboveground organs on the $15 \%$ extract in the case of $L$. multiflorum and the $10 \%$ extract in the case of D. glomerata was inhibited.

\section{Fresh and dry weight and water content}

Compared to control, a significant decrease of the fresh weight values of $T$. pratense for $5 \%$ and higher concentrations of $C$. oleraceum extract were observed. The fresh weight decreased with increasing concentration of allelopathic substances. Compared to the control, the seedlings grown on the $10 \%$ and $15 \%$ extracts showed about the half lower values of the fresh weight, and on the $20 \%$ extracts the values were to 10 times lower. In the case of $L$. multiflorum, differences in the values of this parameter between the control and seedlings on the $10 \%, 15 \%$ and $20 \%$ extracts were found. Statistically significant decrease in the fresh weight of $D$. glomerata seedlings in each concentration of extracts was showed (Table 1).

Compared to the control, the values of the dry weight of significantly increased only for L. multiflorum seedlings in all used extracts. In the other two cases $-T$. pratense and $D$. glomerata, there was no significant effect of water extracts from the leaves of $C$. oleraceum on increasing the dry weight values (Table 1).

The percentage water content of the $T$. pratense seedlings was decreased only on the $20 \%$ extract, compared to the other
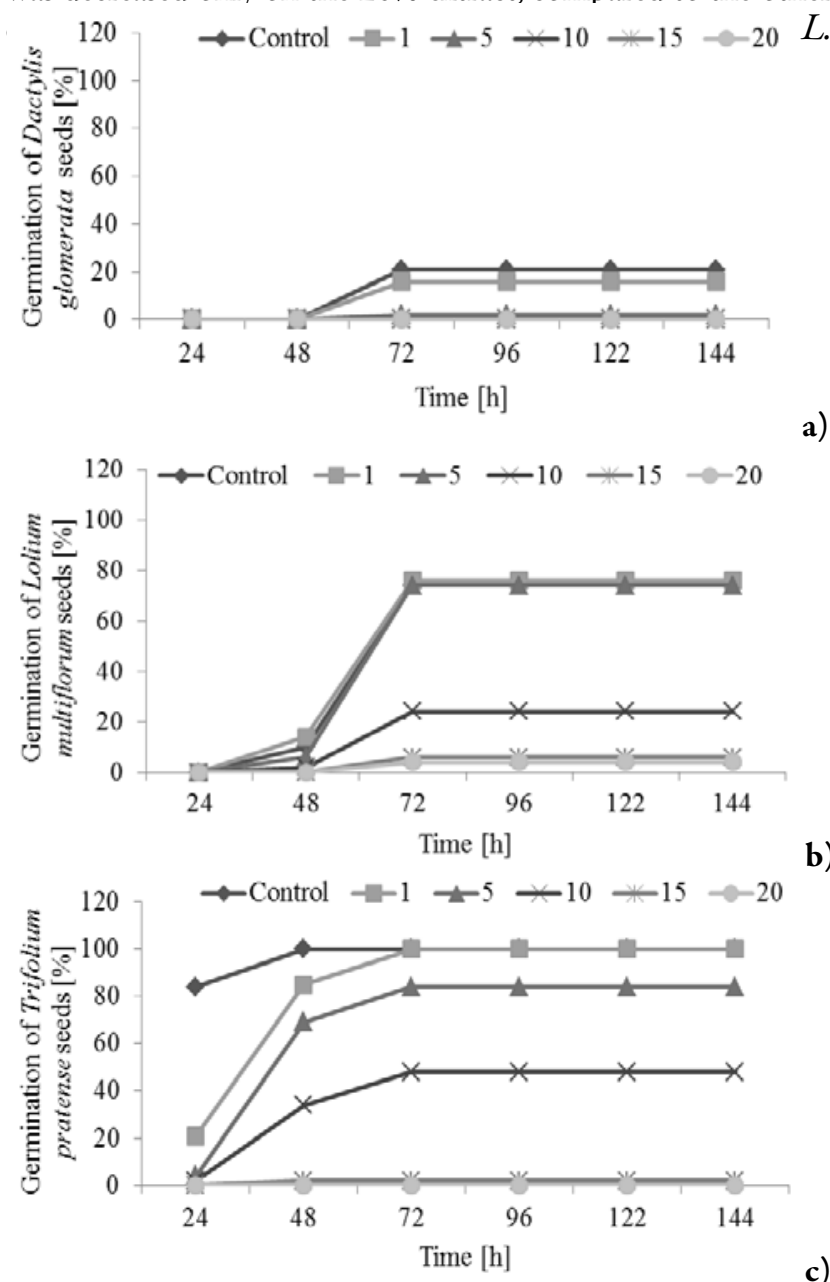

a)

Fig. 2. The influence of the aqueous extracts of the Cirsium oleraceum leaves on the seeds germination: a) Dactylis glomerata; b) Lolium multiflorum; c) Trifolium pratense; mean values $\pm S D, n=5$ 
multiflorum, the values of the water content of the seedlings
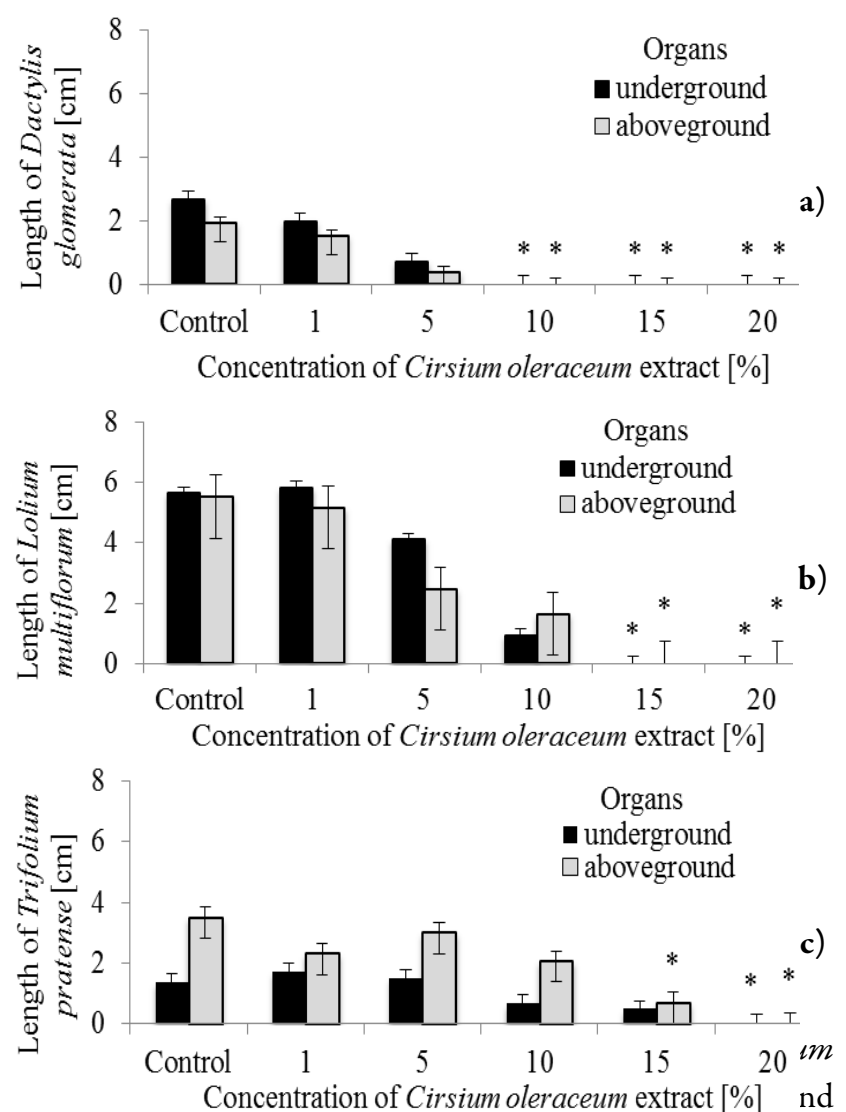

aboveground organs seedlings: a) Dactylis glomerata; b) Lolium multiflorum; c) Trifolium pratense; the mean values \pm SD ( $\mathrm{n}=$ $5)$; columns marked by stars differ significantly by KruskalWallis test at $\mathrm{p} \leq 0.05$ grown in Petri dishes with the lowest concentration of allelopathic substances ( $1 \%$ and $5 \%$ ) were unchanged, compared to the control. In other cases, a significant decrease in water content values, compared to the control and the $1 \%$ and $5 \%$ concentration of extracts were observed. Compared to control, significantly decreasing of the water content in seedlings of $D$. glomerata grown on the $10 \%, 15 \%$ and $20 \%$ extracts of $C$. oleraceum was found (Table 1).

\section{Discussion}

In the Ojców National Park (ONP) already in the 90s of the last century have been found patches of meadow with the dominance of the high nitrophilous perennials, including Cirsium oleraceum (L.) Scop. until 1/5 area of the valley bottom (Kornaś and Dubiel, 1991). They developed on the fertile pastures Lolio-Cynosuretum R.Tx. 1937 and the tall oatgrass meadows Arrhenatheretum elatioris Br.-Bl. ex Scherr. 1925, existing in the ONP in the 50s and later neglected of management. The direct cause of creating this type of plant groups was the abandonment of grazing and mowing. Developing of grasslands with domination Urtica dioica and Cirsium oleraceum resulted in a significant poorness of flora in these areas - in this type of plots recorded only between 10 and 25 species per $100 \mathrm{~m}^{2}$ (Kornaś and Dubiel, 1991). The problem of the occurrence of this community continues to represent a serious threat to biodiversity and landscape of meadows in the valley of the ONP.

Species of the Cirsium Mill. genus are the most common considered as weeds, occurring in different types of crops. With easy vegetative and generative reproduction they can prevail the considerable areas. For example, bull thistle C. vulgare (Savi)

Table 1. The average values of fresh and dry weight and the percentage of water content in seedlings of Dactylis glomerata L., Lolium multiflorum Lam., Trifolium pratense L. germinated on the aqueous extracts of dried leaves Cirsium oleraceum (L.) Scop., at percentage concentrations of 1\%, 5\%, 10\%, $15 \%, 20 \%$ and distilled water (control); the mean values $\pm S D(n=5)$; the different letters within the same row are significantly different by KruskalWallis test at $\mathrm{p} \leq 0.05$

\begin{tabular}{|c|c|c|c|c|c|c|c|}
\hline \multirow{2}{*}{ Name of species } & \multirow{2}{*}{ Parameters } & \multicolumn{6}{|c|}{ Concentration of Cirsium oleraceum extract (\%) } \\
\hline & & Control & 1 & 5 & 10 & 15 & 20 \\
\hline \multirow{6}{*}{$\begin{array}{l}\text { Dactylis } \\
\text { glomerata }\end{array}$} & \multirow{2}{*}{ Fresh weight (g) } & $0.11^{\mathrm{a}}$ & $0.05^{\mathrm{a}}$ & $0.06^{\mathrm{a}}$ & $0.04^{\mathrm{a}}$ & $0.03^{\mathrm{b}}$ & $0.03^{\mathrm{b}}$ \\
\hline & & \pm 0.01 & \pm 0.01 & \pm 0.01 & \pm 0.001 & \pm 0.001 & \pm 0.021 \\
\hline & \multirow{2}{*}{ Dry weight $(\mathrm{g})$} & $0.03^{\mathrm{a}}$ & $0.05^{\mathrm{a}}$ & $0.02^{\mathrm{a}}$ & $0.02^{\mathrm{a}}$ & $0.02^{\mathrm{ab}}$ & $0.009^{\mathrm{abc}}$ \\
\hline & & \pm 0.01 & \pm 0.03 & \pm 0.02 & \pm 0.001 & \pm 0.001 & \pm 0.001 \\
\hline & \multirow{2}{*}{ Water content (\%) } & $72.00^{\mathrm{a}}$ & $65.28^{\mathrm{a}}$ & $64.47^{\mathrm{a}}$ & $39.08^{\mathrm{a}}$ & $33.92^{\mathrm{a}}$ & $32.75^{a}$ \\
\hline & & \pm 13.80 & \pm 2.51 & \pm 3.49 & \pm 4.11 & \pm 4.00 & \pm 15.90 \\
\hline \multirow{6}{*}{$\begin{array}{c}\text { Lolium } \\
\text { multiflorum }\end{array}$} & \multirow{2}{*}{ Fresh weight (g) } & $0.42^{\mathrm{a}}$ & $0.49^{\mathrm{a}}$ & $0.47^{\mathrm{a}}$ & $0.24^{\mathrm{b}}$ & $0.14^{\mathrm{b}}$ & $0.13^{\mathrm{b}}$ \\
\hline & & \pm 0.06 & \pm 0.03 & \pm 0.06 & \pm 0.05 & \pm 0.01 & \pm 0.01 \\
\hline & \multirow{2}{*}{ Dry weight (g) } & $0.04^{\mathrm{b}}$ & $0.06^{a}$ & $0.06^{\mathrm{a}}$ & $0.06^{a}$ & $0.08^{a}$ & $0.08^{a}$ \\
\hline & & \pm 0.01 & \pm 0.006 & \pm 0.008 & \pm 0.007 & \pm 0.004 & \pm 0.05 \\
\hline & \multirow{2}{*}{ Water content (\%) } & $91.77^{\mathrm{a}}$ & $87.51^{\mathrm{a}}$ & $87.38^{\mathrm{a}}$ & $71.12^{b}$ & $46.03^{c}$ & $41.72^{c}$ \\
\hline & & \pm 0.56 & \pm 1.01 & \pm 0.13 & \pm 4.06 & \pm 1.10 & \pm 2.83 \\
\hline \multirow{6}{*}{$\begin{array}{l}\text { Trifolium } \\
\text { pratense }\end{array}$} & \multirow{2}{*}{ Fresh weight (g) } & $0.64^{a}$ & $0.41^{\mathrm{a}}$ & $0.38^{\mathrm{a}}$ & $0.20^{\mathrm{a}}$ & $0.24^{a}$ & $0.06^{\mathrm{b}}$ \\
\hline & & \pm 0.05 & \pm 0.10 & \pm 0.03 & \pm 0.01 & \pm 0.17 & \pm 0.004 \\
\hline & \multirow{2}{*}{ Dry weight (g) } & $0.03^{\mathrm{a}}$ & $0.03^{\mathrm{a}}$ & $0.03^{\mathrm{a}}$ & $0.03^{\mathrm{a}}$ & $0.02^{\mathrm{a}}$ & $0.03^{\mathrm{a}}$ \\
\hline & & \pm 0.001 & \pm 0.002 & \pm 0.004 & \pm 0.0008 & \pm 0.002 & \pm 0.007 \\
\hline & \multirow{2}{*}{ Water content (\%) } & $95.42^{a}$ & $82.03^{\mathrm{a}}$ & $91.75^{\mathrm{a}}$ & $84.54^{\mathrm{a}}$ & $75.81^{\mathrm{a}}$ & $52.51^{b}$ \\
\hline & & \pm 0.23 & \pm 11.30 & \pm 0.64 & \pm 0.68 & \pm 6.01 & \pm 12.46 \\
\hline
\end{tabular}


Ten. is mentioned as a noxious weed crops in nine US states (USDA, NRCS, 2016). In Poland it grows abundantly as a weed of vegetable crops and pastures, drowning out neighboring plants (Nowiński, 1966). Similarly common creeping thistle $C$. arvense (L.) Scop., weeds all types of crops and wrong managed meadows and pastures (Mowszowicz, 1986). Previous studies of species of the Cirsium genus concerned mainly creeping thistle $C$. arvense (Stachoń and Zimdahl, 1980; Uludag et al., 2006; Bhadoria, 2011; Invasive Species Compendium, 2016), marsh thistle C. palustre (L.) Scop. (Falk, 2000), japanese thistle C. japonicum DC. (Chon, 2004), C. pendulum Fisch. and C. vulgare (De Jong and Klinkhmer, 1985). In the literature are available information about their allelopathic interactions. For example Helgeson and Konzak (1950) reported that aqueous extracts from the roots and stalks of $C$. arvense inhibit the germination and growth of wheat Triticum aestivum L. and flax Linum usitatissimum L., and Chon (2004) that the water extracts from the leaves, stalks, roots and flowers $C$. pendulum Fisch. have inhibiting influence on the growth of lucerne seedlings (Medicago sativa L.). Stachon and Zimdahl (1980) noted the fact of $C$. arvense reduced growth of redroot pigweed Amaranthus retroflexus L. and green foxtail Setaria viridis L. more than that of cucumber Cucumis sativus L. or barley Hordeum vulgare L. However, there is not specific information about the allelopathic properties of cabbage thistle $C$. oleraceum.

In the case of cabbage thistle conducted primarily a study to determine the chemical composition of biologically active compounds contained in different parts of this plant, because it is a medicinal and honey species (e.g. Shelyuto el al., 1971; Tarle et al., 1984; Borawska et al., 2010; Kozyra et al., 2015). Active components of the herb (Herba Cirsii oleracei) is a mixture of at least seven flavonoids e.g.: linarin, pectolinarin, apigenin, scutellarin and triterpenes, phytosterols, tannins, pectin, hydrocarbons, resins, essential oils, mineral salts (Nazaruk and Brzóska, 2008). In the inflorescences of $C$. oleraceum were identified essential oils, among them ketones and aldehydes. In small quantities, were shown occurrence of terpenes: thymol, $\beta$ linalool, eugenol, carvacrol and fatty acids with odd number of carbon atoms-waxes (Kozyra et al., 2015). The presence of phenols in extracts from $C$. oleraceum revealed e.g. Borawska et al. (2010) and Nalewajko-Sieliwoniuk et al. (2012). According to some authors, a negative interactions allelopathic species of the Cirsium genus (C. arvense, $C$. japonicum), probably due to the release by their organs phenolic compounds (Kovacs et al., 1988; Kazinczi et al., 2001; Chon et al., 2003). Phenols have inhibiting influence, among others on - ATP synthesis in mitochondria and photosynthesis (Stenlid, 1970; Johansson and Hägerby, 1974; Dadkhah, 2012). They increase the permeability of cell membranes by their depolarisation and inhibition of protein synthesis and play an important role in supplying plants with nutrients (Baziramakenga et al., 1995).

Allelopathic substances have a negative impact on the swelling of seeds, damage of seed coat and aleuronic layer of seeds, inhibition of mitosis and meiosis divisions and cell elongation. The resulting anatomical and morphological distortion delaying seed germination, inhibits germinal root elongation, and lead to their dying off (Rice, 1984). Disorganisation in the functioning of cells, tissues and physiological processes leads to lack of root hairs formation, lateral roots and trend of roots to the horizontal growth which are results of direct contact root with allelopathic substances (Baziramakenga et al., 1994). The morphogenetic changes are the results of influence allelopathic substances which ultimately affects the size and quality of plants (Lyu and Blum, 1990; Skrzypek et al. 2015).

In this study, was demonstrated the inhibitory effect of aqueous extracts of the leaves of $C$. oleraceum on germination and growth of forage species (Trifolium pratense L., Lolium multiflorum Lam., Dactylis glomerata L.) and increase their biomass (Table 1). With increasing concentration of compounds in the extracts, decreasing the number of germinated seeds was observed. The lowest seeds germination on the extracts of $15 \%$ and $20 \%$ were found (Fig. 2a-c). Similarly, at the highest concentrations of extracts from the leaves of $C$. oleraceum the length and weight of seedlings were inhibited (Fig. 3a-c). Significant changes in the morphology of studied seedlings were observed only at the highest concentrations of extracts from the leaves of $C$. oleraceum. It may be result from low amounts of allelopathic substances with inhibitory properties. For example, aqueous extracts of the leaves of peppermint (Mentha $\times$ piperita L.) already at concentrations of $3 \%$ and $5 \%$ inhibited germination of common sunflower (Helianthus annuus L.) (Skrzypek et al., 2015), and aqueous extracts from the roots and stems of the Shepherd's purse Capsella bursa-pastoris (L.) Medik. at $1 \%$ concentration inhibited the germination of lettuce seeds Lactuca sativa L. cv 'Maryna' (Możdżeń et al., 2016).

It should also be noted that the activity of allelopathic substances is correlated with various environmental stresses. In natural conditions, about the growth and development of plants decide simultaneously environmental factors and allelochemical substances in them appearing (Astarita et al., 1996). One of the most important abiotic factors of the environment for plants is the availability of light (Franklin and Whitelam, 2005). The light provides various informations about plants and the surrounding environment. In natural conditions, some plants are exposed to shade and others on excessive sunlight (Smith and Whitelam, 1997). In response to the various spectral composition and intensity of light, the plants are characterised by different morphology and different physiological processes (Casal, 2012). C. oleraceum due to its large size and large surface of leaves, through most of the day has easy access to sunlight. Other species, such as $L$. multiflorum, $D$. glomerata, especially $T$. pratense, growing around $C$. oleraceum, for the major part of the day are exposed to low light, because they grow in its shadow. The reduction of light through the plant canopy affects the same on changes in temperature, humidity and soil. C. oleraceum has a relatively low allelopathic effect, but the interaction with environmental stress factors such as shading, the effect can be improved. Depending on the species and stage of development of plants growing around cabbage thistle, in a higher or lower degree, $C$. oleraceum interferes in biochemical and physiological processes these plants.

\section{Conclusions}

The highest of energy germination was observed in Trifolium seeds, and the lowest in Dactylis; at the extract with 
260

concentrations of $15 \%$ and $20 \%$, energy and power of seeds germination of all three species were the lowest; the most sensitive to the aqueous extracts of Cirsium were Dactylis seeds. Hypocotyl growth was significantly lower for all used extracts, especially with the largest concentration allelopathic substances; All extracts have inhibitory effects on root and coleoptyle growth of Dactylis, and Lolium seedlings were insensitive only on the $1 \%$ extract. The fresh weight of Trifolium seedlings decreased with increasing concentrations of extracts; at $10 \%, 15 \%$ and $20 \%$ concentrations changes in the quantity of fresh weight in Lolium were recorded; used at each of the extracts, the fresh weight of the Dactylis seedlings oscillated at a very low range; the highest value of the dry weight of the Lolium seedlings was observed, and the lowest in Dactylis seedlings. For each of the applied aqueous extracts, the water content in seedlings had highest value in case of Trifolium and lower values in case of Dactylis and Lolium.

Based on the above conclusions, answer the question posed in the aim of this study - whether has the C. oleraceum ability to allelopathic influence on the sward meadow species? - can be in the following way: $C$. oleraceum has the ability to allelopathic influence on the sward meadow species, however, in compared to the other plants demonstrates lower properties. Therefore it must be assumed that its competitive success is the result not only of allelopathic interactions, but relatively large size of individuals, that cause effective shading of other sward species.

\section{References}

Ahmed M, Wardle DA (1994). Allelopathic potential of vegetative and flowering ragwort (Senecio jacobea L.) plants again associated pasture species. Plant Soil 164:61-68.

Astarita LV, Ferreira AG, Bergoni JI (1996). Mimosa bimuctonata: Allelopathy stress. Allelopathy Journal 3:43-50.

Baziramakenga R, Leroux GD, Simard RR (1995). Effects of benzoic and cinnamic acids on membrane permeability of soybean roots. Journal of Chemical Ecology 21:1271-1285.

Baziramakenga R, Simard RR, Leroux GD (1994). Effects of benzoic and cinnamic acids on growth, mineral composition, and chlorophyll content of soybean. Journal of Chemical Ecology 20:2821-2833.

Bhadoria PBS (2011). Allelopathy: A natural way towards weed management. American Journal of Experimental Agriculture 1(1):7-20.

Borawska MH, Czechowska SK, Markiewicz R, Socha K, Nazaruk J, Pałka J, Isidorov VA (2010). Enhancement of antibacterial effects of extracts from Cirsium species using sodium picolinate and estimation of their toxicity. Natural Product Research 24:554-61.

Casal JJ (2012). Shade avoidance. The Arabidopsis Book. The American Society of Plant Biologists 10:e0157.

Chon SU (2004). Allelopathic potential of common thistle (Cirsium japonicum) leaf extracts and residues. Korean Journal of Weed Science 24:79-86.

Chon SU, Kim YM, Lee JC (2003). Herbicidal potential and quantification of causative allelochemicals from several Compositae weeds. Weed Research 43:444-450.
Dadkhah A (2012). Phytotoxic effects of aqueous extract of eucalyptus, sunflower and sugar beet on seed germination, growth and photosynthesis of Amaranthus retroflexus. Allelopathy Journal 29(2):287-296.

De Jong TJ, Klinkhmer PGL (1985). The negative effects of litter of parent plants of Cirsium vulgare on their offspring: autotoxicity or immobilization? Oecologia 65(2):153-160.

Falk A (2000). Allelopathic effect of invasive wetland plants (Lythrum salicaria, Cirsium palustre, Rhamnus frangula) on seed germination. General Ecology. Deep Blue at the University of Michigan. http://hdl.handle.net/2027.42/54882.

Franklin KA, Whitelam GC (2005). Phytochromes and shadeavoidance responses in plants. Annals of Botany 96(2):169-75.

Helgeson EA, Konzak R (1950). Phytotoxic effects of aqueous extracts of field bindweed and of Canada thistle. A preliminary report. North Dakota Agricultural Experiment Station Bulletin 12:71-76.

Invasive Species Compendium (2016). Cirsium arvense (creeping thistle). Retrieved 2016 December 7 from http://www.cabi.org/ isc/datasheet/13628.

Johansson M, Hägerby E (1974). Influence of growth conditions, metabolic inhibitors, and phenolic compounds on the ATP pool in Fomes annosus. Physiologia Plantarum 32:23-32.

Kazinczi G, Beres I, Narwal SS (2001). Allelopathic plants. 1. Canada thistle (Cirsium arvense (L.) Scop.). Allelopathy Journal 8:29-40.

Kornaś J, Dubiel E (1991). Land use and vegetation changes in haymeadow in the Ojców National Park during last thirty years. Veröffentlichungen des Geobotanischen Institutes ETH, Zürich, Stiftung Rübel 106:209-231.

Kovacs L, Mikulas J, Polos E (1988). Allelopathic activity of Cirsium arvense (L.) in Hungary. Acta Agronomica Hungarica 37:65-69.

Kozyra M, Mardarowicz M, Kochmańska J (2015). Chemical composition and variability of the volatile components from inflorescences of Cirsium species. Natural Product Research 29(20):1942-1944.

Lyu SW, Blum U (1990). Effects of ferulic acid, an allelopathic compound, on net $\mathrm{P}, \mathrm{K}$ and water uptake by cucumber seedlings in a split-root system. Journal of Chemical Ecology 16:2429-2439.

Matuszkiewicz W (2006). Przewodnik do oznaczania zbiorowisk roślinnych Polski [Guide for the determination of Polish plant communities]. Wydawnictwo Naukowe PWN, Warszawa.

Mowszowicz J (1986). Krajowe chwasty polne i ogrodowe. Przewodnik do oznaczania. [Guide for the determination of plants]. Państwowe Wydawnictwo Rolnicze i Leśne, Warszawa.

Możdżeń K, Barabasz-Krasny B, Sołtys-Lelek A, Stachurska-Swakoń A Puła J (2016). Wpływ wodnych ekstraktów z tasznika pospolitego (Capsella bursa-pastoris (L.) Medik.) na kiełkowanie i rozwój sałaty siewnej odmiany 'Maryna' (Lactuca sativa L. cv 'Maryna'). Annales Universitatis Mariae Curie-Skłodowska, Sectio E 71(2):1-10.

Nalewajko-Sieliwoniuk E, Nazaruk J, Kotowska J, Kojło A (2012). Determination of the flavonoids/antioxidant levels in Cirsium oleraceum and Cirsium rivulare extracts with cerium (IV)rhodamine 6G chemiluminescence detection. Talanta 96:216-222. 
Nawara Z (2006). Rośliny łąkowe. Flora Polski. Oficyna wydawnicza Multico, Warszawa.

Nazaruk J, Brzóska T (2008). Aktualny stan wiedzy na temat aktywności farmakologicznej roślin z rodzaju Cirsium Mill. Postępy Fitoterapii 3:170-175.

Nowiński M (1966). Chwasty ląk i pastwisk. Państwowe Wydawnictwo Rolnicze i Leśne, Warszawa.

RiceEL (1984). Allelopathy, Academic Press (2 ${ }^{\text {nd }}$ ed), Orlando, Florida.

Shelyuto VL, Glyzin VI, Ban’kovskii AI, Bubon NT (1971). Flavonoid glycosides of Cirsium oleraceum. Khimiya Prirodnykh Soedinenii $7(3): 372-373$.

Skrzypek E, Repka P, Stachurska-Swakoń A, Barabasz-Krasny B, Możdżeń K (2015). Seedlings growth of common sunflower under influence of peppermint extract. Modern Phytomorphology 9:6973.

Smith H, Whitelam GC (1997). The shade avoidance syndrome: multiple response mediated by multiple phytochromes. Plant, Cell \& Environment 20:840-944.
Stachoń WJ, Zimdahl RL (1980). Allelopathic activity of Canada thistle (Cirsium arvense) in Colorado. Weed Science 28(1):83-86.

Stenlid G (1970). Flavonoids as inhibitors of the formation of adenosine triphosphate in plant mitochondria. Phytochemistry 9:2251-2256.

Tarle D, Petricic J, Kupinic M (1984). Cirsium oleraceum (L.) Scop. Chemical and anti-microbial investigation. Farm Glas 40(1112):363-367.

Uludag A, Uremis I, Arslan M, Gozcu D (2006). Allelopathy studies in weed science in Turkey - a review. Journal of Plant Diseases and Protection 20:419-426.

USDA, NRCS. 2016. The Plants Database (http://plants.usda.gov, 7 December 2016). National Plant Data Team, Greensboro, NC 27401-4901 USA.

Wójcik-Wojtkowiak D, Politycka B, Weyman-Kaczmarkowa W (1998). Allelopathy. Wydawnictwo Akademii Rolniczej, Poznań. 